\title{
Synthesis, Characterization and Antimicrobial activity Study Via some new Schiff bases for Trimethoprim
}

\author{
Saadiyah A. Dhahir " Sanaa A.Al-Sahib * \\ Nafeesa J. Kadhim* \\ Date of acceptance $1 / 3 / 2010$
}

Wasan A. Al Razaq

\begin{abstract}
:
This search reports the synthesis of some new series of Schiff base compounds for trimetheprim derivatives which known high been known as a medicinal effectiveness. Trimetheprim was condensed with several substituted aldehydes compounds.(4dimethyl amine benzaldehyde, propanal, salicaldehyde, 2.4 dimethoxy benzaldehyde and 4- methyl benzaldehyde) to obtain Schiff base products(1a-5a) and several substituted ketones compound (4-aminoacetophenone,4-chloroacetophenone, isobutyleketone, acetylacetone and acetophenone) to obtain Schiff base products(6b10b) in ethanol in the presence of concentrated sulphuric acid as a catalyst to yield the Schiff base. The structure of synthesized compounds has been established on the basis of their Chemical structures of all products were confirmed by spectrophotometric methods such as U.V. visible and FTIR.. All these compounds were evaluated for their antibacterial activity in vitro against Gram + ve bacteria (bacillus), Gram -ve bacteria (E-Coli).Most Compound under investigation exhibited potent antibacterial activity
\end{abstract}

Keywords: Ttrimetheprim, Schiff bases, aldehyde .ketone, antibacterial activity.

\section{Introduction}

Schiff bases are a class of important compounds in medicinal and pharmaceutical field. They show biological activities including antibacterial [1-4], antifungal [5,6], anticancer[7-9], and herbicidal[10] activities . Furthermore Schiff bases have been widely used as protective group of amino group in organic synthesis[11,12].

Trimethoprim and Trimethoprim derivative is a type of medicine called an antibiotic[13]. It is used to treat infections with bacteria[14]., it is a significant antimicrobial activities $[15,16]$, and its analogues[17]. The chemical designation of Trimethoprim is 2,4-diamino-5-(3,4,5-

trimethoxypenzyl)pyrimidine

$\mathrm{C}_{14} \mathrm{H}_{18} \mathrm{~N}_{4} \mathrm{O}_{3}$. was first describe by Roth and co-workers[15] It is a white to yellowish compound with bitter taste. The trade names of the combined product are Bactrim and Spectra[14]

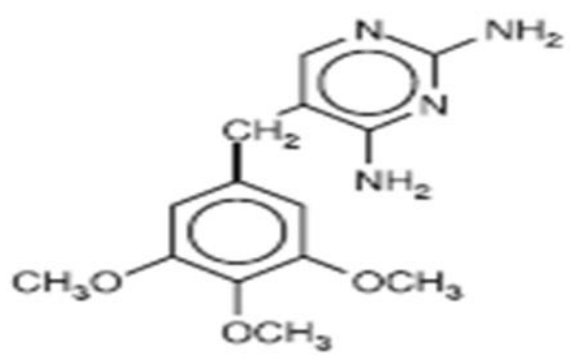

* Department of Chemistry, College of Science for women, University of Baghdad, Iraq. 
In organic synthesis, Schiff base reactions are useful in making carbonnitrogen bonds, compounds containing azomethin group $(-\mathrm{CH}=\mathrm{N}-)$ are known Schiff bases. Schiff they are usually formed by condensation of a primary amine with a carbonyl compounds[18]., the general formula of Schiff bases $\mathrm{R}_{1} \mathrm{R}_{2} \mathrm{C}=\mathrm{N}-\mathrm{R}_{3}$, where $\mathrm{R}_{1}, \mathrm{R}_{2}, \mathrm{R}_{3}$ is may be an aliphatic or an aromatic group [19]

Schiff bases derived from aliphatic amines and salicylaldehyde drew the interest of many workers based on their antitumor activities which has been investigated on different Schiffbase ligands[20].

In current study we prepare some the new derivative of Schiff base compounds of Trimethoprim and study the effect of these compounds on the antimicrobial activity it was thought that the new derivatives can provide a wide choice and flexibility to change structure in order to find a less toxic derivatives with enhanced activity.

The selection of bacterial strains was made because the trimethoprim possessed anti-microbial spectrum witch include all gram positive and negative bacilli. therfor, with altered structure, it was envisaged to see this modified structure could as well inhibit gram positive and negative bacteria.

\section{Material and Methods}

All chemicals were high purity are used as the manufactures spilled them The FTIR spectra in the range (4000-200) $\mathrm{cm}^{-1}$ were recorded as $\mathrm{KBr}$ disc on a Shimadzu IR prestige -21 spectrophotometer, UV-visible spectra in the range $(200-1100) \mathrm{nm}$ were carbonyl compound by mechanism of nucleophilic addition. The following Scheme explain the reaction: recorded using Shimadzu UVvis. 160A.Ultra-violet spectrophotometer. Melting point were recorded on a hot stage Gallen Kamp melting point apparatus.

\section{Material and methods \\ Preparation of Schiff base}

A series of Schiff base were prepared by reacting trimethoprim drug with different compounds of aldehydes and ketones by mixing equal amounts of (1mole)aldehyds compounds or (1mole)ketones compounds with (1mole)Trimethoprim, and dissolved with(25)ml Ethanol one drop of concentrated sulphuric acid was added, the mixture was refluxed for approximately 3 hour under $70 \mathrm{C}^{\circ}$.

Then cool the products of trimetoprim schiff base, filtrated off, washed with ethanol, purification by recrystallization in ethanol and dried under vacuum and kept in adesicator till further use.All derivatives of trimetoprim schiff base were given in table (1)

\section{Bacteriology}

Biological activity of new
compound prepared representative gram-positive and gram negative bacteria by agar plate methods ${ }^{(21)}$ all compounds were prepared dissolving them with distill water to obtain final concentration of $30 \mathrm{ppm}$ and cultivated in nutrient agar the results are found in table (3).

\section{Discussion}

The new derivative for Trimethoprim Schiff bases can be synthesized from condensing Trimethoprim with varies 


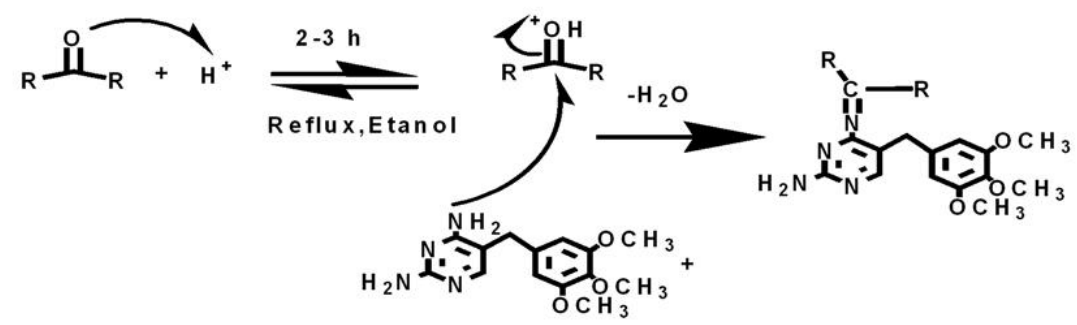

$\mathbf{R}=\mathbf{H}, \mathbf{A}$ lk $\mathbf{y} \mathbf{l}, \mathbf{A}$ ry $\mathbf{l}$

Many anew compounds of Schiff base were isolated and characterized by ,melting point and spectroscopic data ..all compounds prepared were found to be stable at room temperature. The physical properties of the new Schiff base of trimethoprim compounds with varies aldehydes(1a-5a) and ketones (6b-10b)compound, which prepared, are listing in table (1).

Table Physo-Chemical data of synthesized Schiff Base of anew Trimethoprim Schiff bases

\begin{tabular}{|c|c|c|c|c|c|}
\hline No. & $\begin{array}{c}\text { Molecular } \\
\text { structure }\end{array}$ & Color & $\begin{array}{c}\text { Molecular } \\
\text { weight }\end{array}$ & $\begin{array}{c}\text { Melting } \\
\text { point } \mathbf{C}^{0}\end{array}$ & $\begin{array}{c}\text { Electronic spectra } \\
\lambda_{\text {max }} \text { nm)/ Ethanol }\end{array}$ \\
\hline 1a & $\mathrm{C}_{21} \mathrm{H}_{22} \mathrm{~N}_{4} \mathrm{O}_{3}$ & light yellow & 378.42 & $75-79$ & $220,304,610$ \\
\hline 2a & $\mathrm{C}_{17} \mathrm{H}_{22} \mathrm{~N}_{4} \mathrm{O}_{3}$ & light Brown & 330.38 & -185 & $212,304,540$ \\
\hline 3a & $\mathrm{C}_{21} \mathrm{H}_{22} \mathrm{~N}_{4} \mathrm{O}_{4}$ & Organ & 394.42 & $152-155$ & $218,334,644$ \\
\hline 4a & $\mathrm{C}_{23} \mathrm{H}_{26} \mathrm{~N}_{4} \mathrm{O}_{5}$ & Dark Brown & 438.48 & $105-108$ & $221,301,331,819$ \\
\hline $\mathbf{5 a}$ & $\mathrm{C}_{22} \mathrm{H}_{24} \mathrm{~N}_{4} \mathrm{O}_{3}$ & Yellow & 392.45 & $83-85$ & $224,304,615$ \\
\hline 6b & $\mathrm{C}_{22} \mathrm{H}_{25} \mathrm{~N}_{5} \mathrm{O}_{3}$ & Light Yellow & 407.47 & 108 & $213,332,403,570$ \\
\hline 7b & $\mathrm{C}_{21} \mathrm{H}_{20} \mathrm{ClN}_{4} \mathrm{O}_{2} \cdot$ & Brown & 395.86 & 175 & $214,304,627$ \\
\hline $\mathbf{8 b}$ & $\mathrm{C}_{18} \mathrm{H}_{24} \mathrm{~N}_{4} \mathrm{O}_{3}$ & Dark Yellow & 344.41 & 185 & $213,301,415$ \\
\hline 9b & $\mathrm{C}_{19} \mathrm{H}_{24} \mathrm{~N}_{4} \mathrm{O}_{4}$ & Yellow & 372.42 & 176 & $302,348,720$ \\
\hline 10b & $\mathrm{C}_{22} \mathrm{H}_{24} \mathrm{~N}_{4} \mathrm{O}_{3}$ & $\begin{array}{c}\text { Moderate } \\
\text { Yellow }\end{array}$ & 392.45 & 208 & $215,304,738$ \\
\hline
\end{tabular}

The formula structure of Schiff base Trimethoprim derivatives were identificated by IR spectroscopy which explain in table(2) 
Table (2): The value of IR spectroscopy for some functional group in trimethoprim Schiff bases.

\begin{tabular}{|c|c|c|c|c|c|c|}
\hline No. & $\begin{array}{l}\mathrm{C}=\mathrm{N} \\
\text { str. } \\
\mathrm{cm}^{-1}\end{array}$ & $\begin{array}{l}\mathrm{C}=\mathrm{N} \\
\text { bend. } \\
\mathrm{cm}^{-1}\end{array}$ & $\begin{array}{c}\text { CH } \\
\text { Aldehayd }\end{array}$ & $\begin{array}{l}\mathrm{C}=\mathrm{C} \\
\text { Aromatic } \\
\text { str. } \mathbf{c m}^{-1}\end{array}$ & $\begin{array}{c}\text { CH } \\
\text { Aliphatic } \\
\text { cm }^{-1}\end{array}$ & $\begin{array}{c}\text { Other } \\
\text { cm }^{-1}\end{array}$ \\
\hline 1a & 1654 & 1636 & 3475 & 1458 & 2997 & Aromatic CH str. 3114 \\
\hline 2a & 1636 & $\begin{array}{l}1597 \\
1566\end{array}$ & 3420 & 1508 & 2938 & NH str.3329,3388 \\
\hline $3 \mathbf{a}$ & 1589 & 1504 & 3379 & 1458 & 2823 & Aromatic CH str. 3047 \\
\hline $4 a$ & 1640 & 1634 & 3377 & 1451 & 2953 & $\begin{array}{c}\text { Aromatic CH str. } 3020 \\
\text { Out of plan CH bend. } 742\end{array}$ \\
\hline $5 a$ & 1640 & 1635 & 3392 & 1433 & 2927 & $\begin{array}{c}\text { Aromatic CH str. } 3030 \\
\text { Out of plan } \mathrm{C}=\mathrm{C} \text { bend. } 502\end{array}$ \\
\hline $6 \mathrm{~b}$ & 1636 & 1589 & - & 1423 & 2835 & $\begin{array}{c}\mathrm{NH} \text { str. } 3394,3329 \\
\text { Aromatic CH str. } 3120\end{array}$ \\
\hline $7 \mathrm{~b}$ & 1644 & 1625 & - & 1458 & 2877 & $\begin{array}{l}\text { Aromatic CH str.3030 } \\
\text { C-Cl str.1000-1100 }\end{array}$ \\
\hline $\mathbf{8 b}$ & 1651 & 1544 & - & 1488 & 2865 & Aromatic CH str. 3108 \\
\hline 9b & 1654 & 1458 & - & 1508 & 2855 & $\begin{array}{c}\text { Aromatic CH str. } 3124 \\
\text { Out of plan } \mathrm{C}=\mathrm{C} \text { bend. } 505\end{array}$ \\
\hline $10 \mathrm{~b}$ & 1635 & 1597 & - & 1458 & 2836 & $\begin{array}{c}\text { NH str.3491 } \\
\text { Aromatic CH str.3109 }\end{array}$ \\
\hline
\end{tabular}

The important diagnostic bands in the IR spectra were assigned and the band positions are compiled in Table 2 . and figures The infrared absorption spectra of all the trimethoprim Schiff bases(1a-10b) compounds indicate the formation of Schiff base product by the absence of the carbonyl group (1700 $\mathrm{cm}^{-1}$ ) band and the appearance of a strong band in the region of $(1589$ $\left.1654 \mathrm{~cm}^{-1}\right)$, assignable to the $v(\mathrm{C}=\mathrm{N})$ imine group ${ }^{(22)}$.

The disappearance of absorption for the $\mathrm{NH}_{2}$ group that it be secondary demonstrate in the region (3000-3400) $\mathrm{cm}^{-1}$ (23) is not clearly that to give reason for one of the $\mathrm{NH}_{2}$ group that is situated in position 4 between two nitrogen atoms in the pyrimidine cycle is not inter reaction, may be the hydrogen atom in this amine group enter tautomerism with the neighboring nitrogen atoms

The frequency of stretch $(\mathrm{C}=\mathrm{C})$ aromatic when (1423-1508) $\mathrm{cm}^{-1}$ and frequencies of the benzene ring substitutes, the $\mathrm{C}-\mathrm{X}(\mathrm{X}=\mathrm{Cl}$, ) bond on the phenyl ring led to the appearance of a strong absorption band at 1000$1100 \mathrm{~cm}^{-1}$ as in Table (2)

The electronic absorption spectra of the Schiff bases under investigation were measured in ethanol the Schiff bases in ethanol are characterized by mainly bands (Table 1).

The first band at $\lambda$ max $=212-224 \mathrm{~nm}$ can be assigned to the medium energy $\pi-\pi^{*}$ transition of the aromatic ring, while the second band at $\lambda_{\max }=301$ $348 \mathrm{~nm}$. is due to the low energy $\pi-\pi^{*}$ transition.. Other absorption bands that weak absorbance demonstrate in the visible region up $403 \mathrm{~nm}$ which is present in the spectrum of the free amine, is assigned to an intermolecular charge transfer absorption involving the whole molecule. for Schiff bases . this weak peak give reason of produce color

Table 3 : biological activity of trimethoprim Schiff bases.

\begin{tabular}{|c|c|c|}
\hline $\begin{array}{c}\text { Comp 30 } \\
\mathbf{~ m g / l}\end{array}$ & $\begin{array}{c}\text { Activity against } \\
\mathbf{G}^{-} \\
\text {bacteria } \mathbf{E}^{-} \text {Coil }\end{array}$ & $\begin{array}{c}\text { Activity against } \\
\mathbf{G}^{+} \\
\text {bacteria } \\
\text { Bacillus }\end{array}$ \\
\hline 1a & ++ & ++ \\
\hline 2a & - & + \\
\hline 3a & + & ++ \\
\hline 4a & ++ & ++ \\
\hline 5a & - & + \\
\hline 6b & ++ & ++ \\
\hline $7 \mathbf{b}$ & ++ & ++ \\
\hline 8b & + & ++ \\
\hline 9b & + & + \\
\hline 10b & - & + \\
\hline
\end{tabular}

(-) No inhibition

(+) Inhibition diameter of 20-25 mm

$(++)$ Inhibition of $25-30 \mathrm{~mm}$ in diameter 
The biological activity were studied the effect of some Schiff base compounds on two type of bacteria $\left(\mathrm{G}^{-}\right.$ E-coil and $\left(\mathrm{G}^{+}\right)$Bacillus have been described in table3.and showed in figure 3 , all the synthesized compounds were screened for their antibacterial activity by agar dilution methods. the selection of the bacterial strains was made because the trimethoprim processed antimicrobial spectrum witch included all gram positive bacilli. Therefore with altered structure could as well inhibit gram negative bacteria.

some of these derivatives have shown high activity These results confirm the fact that compounds with $(\mathrm{NH}$, and $\mathrm{OH})$ with Schiff base have great potential as antibacterial agents.

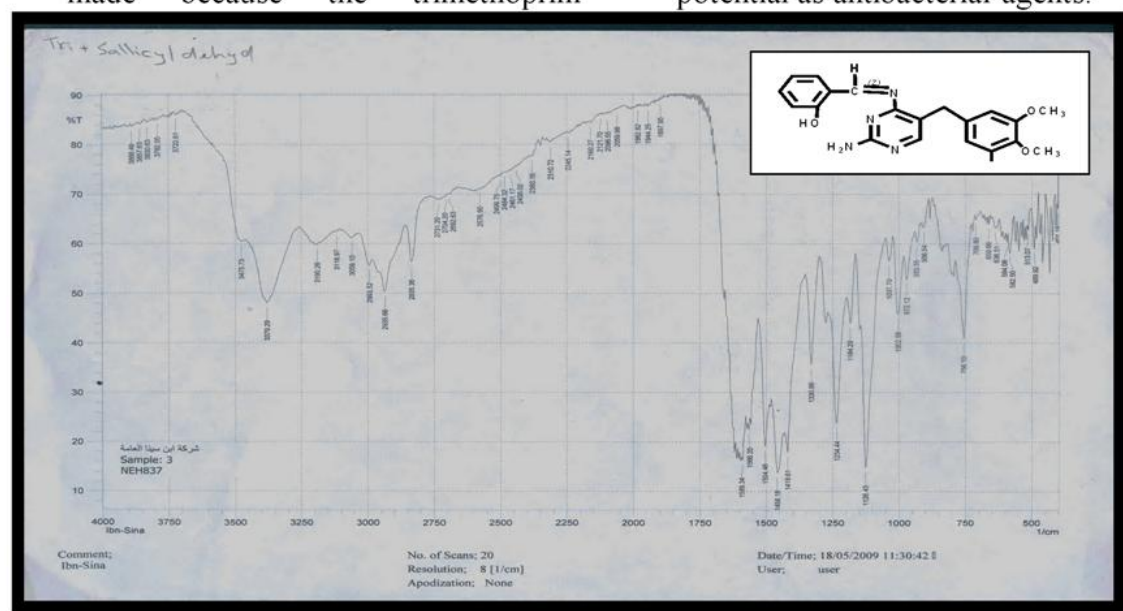

Figure1:Salicylidene trimethoprim

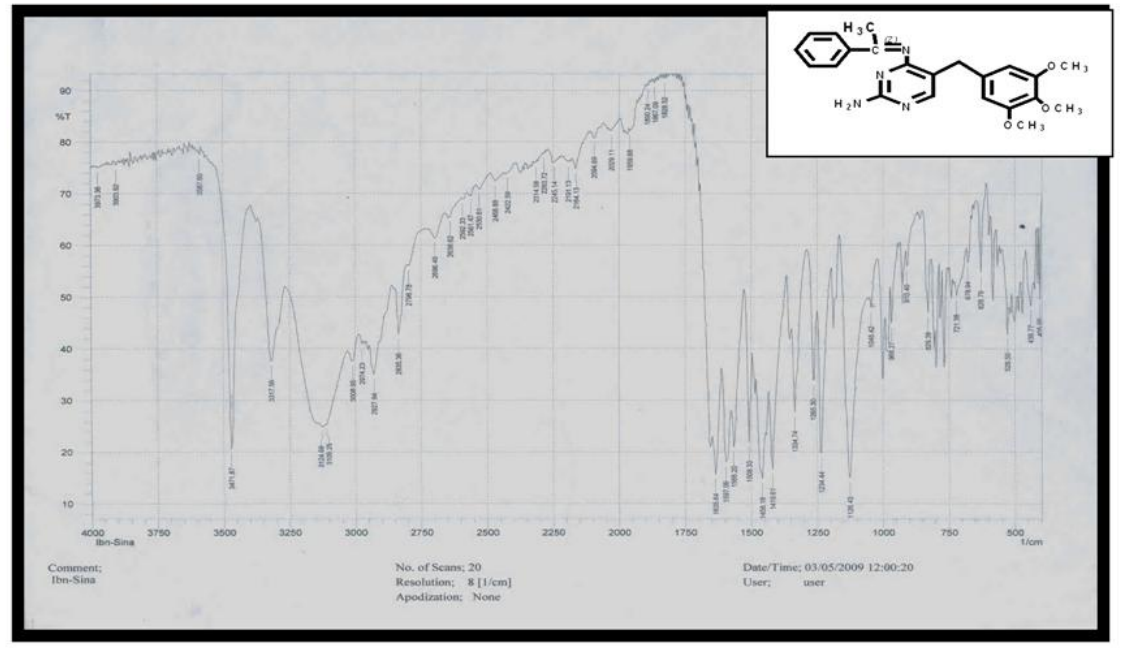

Figure2: Phenyl-ethylidene trimethoprim 


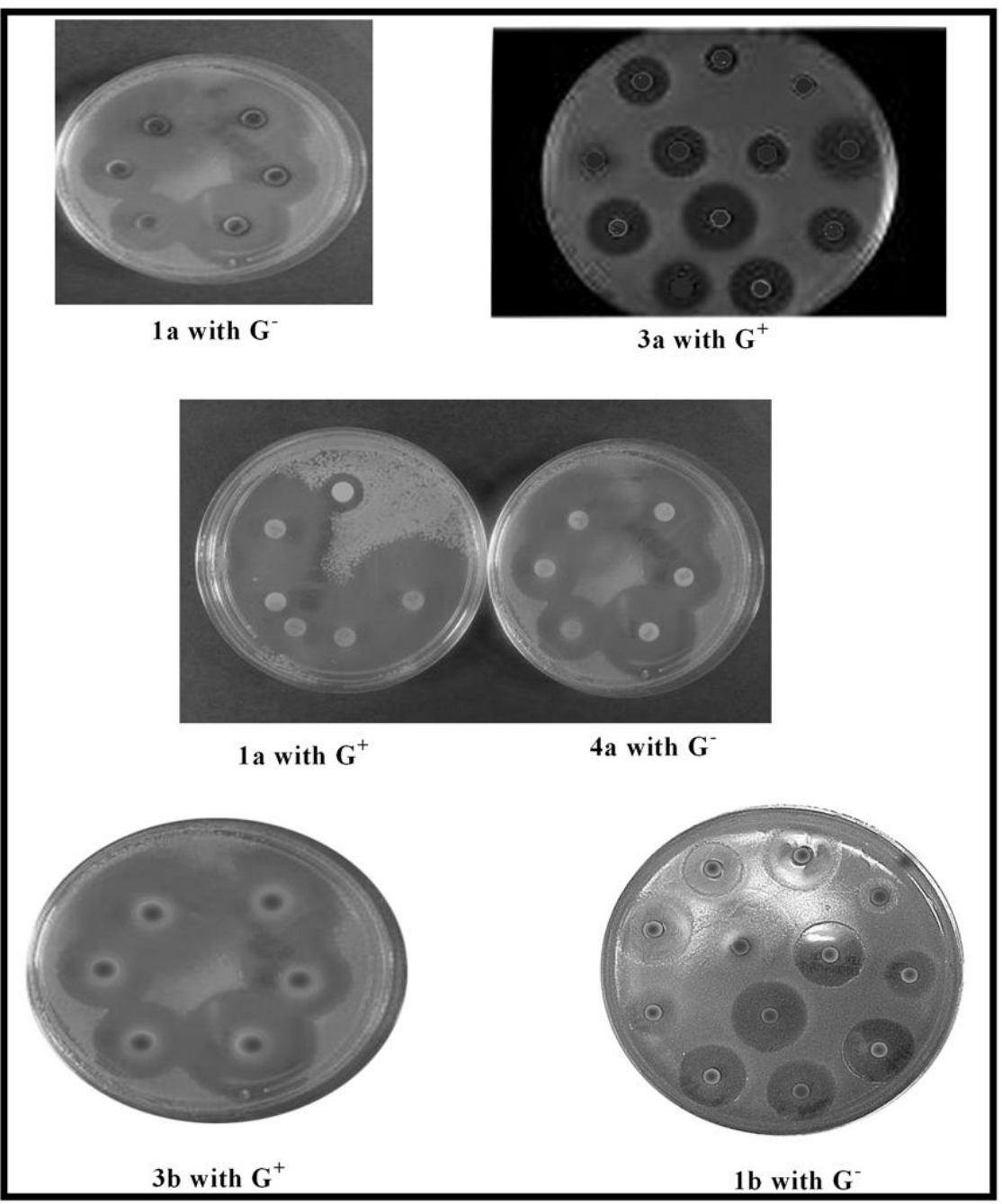

Figure 3:the biological activity of some compounds prepared.

\section{References}

1. Karia, F. D.;Parsania, P. H .Asian J. Chem. 1999, 11 (3), 991-995.

2. More, P. G.;Bhalvankar, R B.;Pattar, S. C.,.J. Indian Chem.Soc. 2001, 78 (9), 474-475

3. El-masry, A. H.; Fahmy,H. H.; Abdelwahed, S. H. A.Molecules 2000, 5, 1429-1438

4. Baseer, M. A.; Jadhav, V. D.; Phule, R. M.; Archana, Y. V.;
Vibhute, Y. B. Orient. J. Chem.2000, 16 (3), 553-556.

5. Pandeya, S. N.; Sriram, D.; Nath, G.; De Clercq, E. IL Farmaco 1999, 54, 624-628

6. Singh, W. M.; Dash, B C.Pesticides, 1988, 22(11), 33-37

7. Hodnett, E. M. and Dunn, W. J..J. Med. Chem. 1970, 13, 768-770

8. Desai, S. B.; Desai, P. B.; Desai,K.R., Hetrocycl. Commun. 2001, 7(1), 83-90. 
9. Pathak, P.; Jolly, V. S.; Sharma,K. P.Oriental. J. Chem. 2000, 16(1), 161-162.

10. Samadhiya, S.; Halve, A. Orient. J .Chem. 2001, 17 (1), 119-122

11. P. Bey and J. P.Vevert, Tetrahedron Lett., 18, 1455 (1977).

12. R. A. Lucas, D. F. Dickel, M. J. Dziemian, B. L. Hensle, and H. B. MacPhillamy, J. Am. Chem. Soc., $82,5688(1960)$.

13. Dr. Karl Thomae GmbH (Biberach an der Riss, DE), United States Patent,4829058., Substituted bis(4-aminophenyl)-sulfones Publication Date:05/09/1989 International Classes:C07C205/26; C07C205/34; C07C205/00; $\mathrm{C} 07 \mathrm{C} 103 / 22$

14. Bean DC, Livermore DM, Papa I, Hall LM (November 2005). "Resistance among Escherichia coli to sulphonamides and other antimicrobials now little used in man". J Antimicrob Chemother 56 (5): 962-4.

15. Bong Young Chung and Chae Ho Lee, Anew route to $3,4,5$ Trimethoxybenzylmanolate
aTriethoprim Intermediate., Journal of the korian chemical society, Vol29,No. 5, 1985

16. B.Roth,E.A.Falco,, G.H.Hitchingsa nd S.R.M.Bushby,J.Med.Pharm chem., 5, 1103(1962).

17. S.R.M. Bushby and C.W.Sigel J.Med .Chem.,24,933 (1981). And refernces cited therein.

18. International Union of Pure and Applied Chemistry. "Schiff base". Compendium of Chemical Terminology Internet edition.

19. International Union of Pure and Applied Chemistry. "anils". Compendium of Chemical Terminology Internet edition.

20. Hossein E-H., Mohammad R. H., Ali B., Samaneh B., A. Ali E., Malihe, Ali M., Spectrochimica Acta Part A 71 (2008) 1341-1347.

21. A.R.Ohi,H.Iwano, T.Shishdo,I.Shi mamura,Ger.Offen, 1,35,1970.

22. R. F. Lindloy, L.G. Armstrong, Inorg. Chem. 1975, 14,1332.

23. Silverstein G.T.,1981., Spectrometric identification of organic copounds.,4Ed

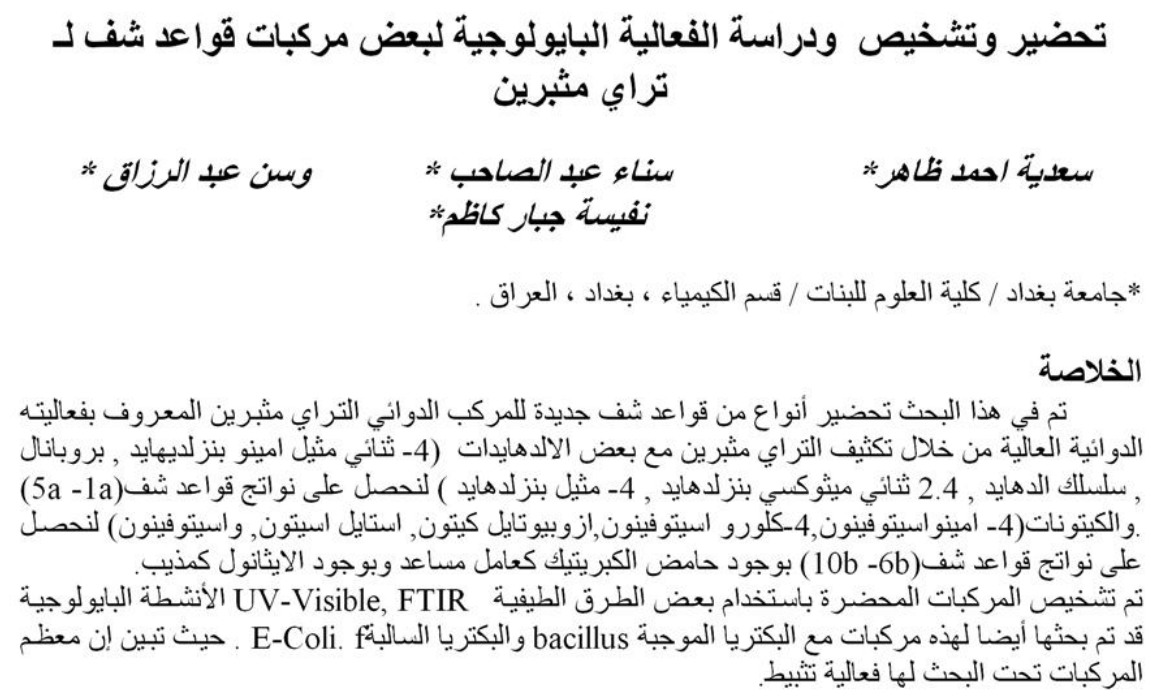

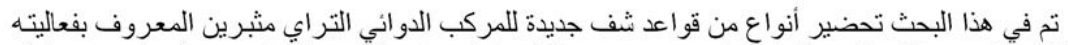

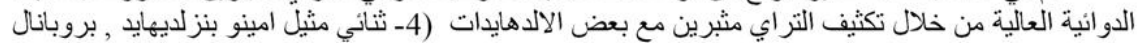

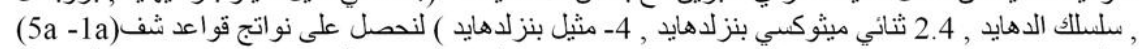

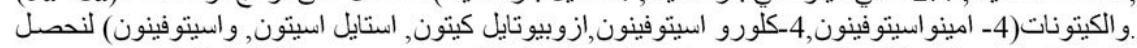

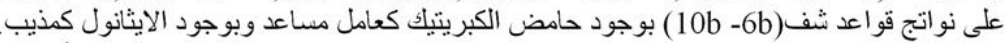

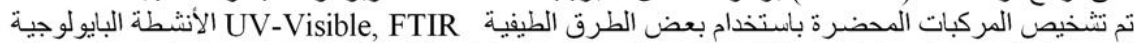

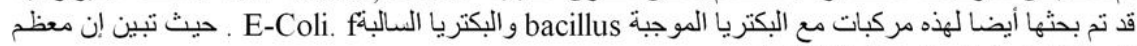
المركبات تحت البحث لها فعالية تثبيط. 